\title{
A STUDY OF ORGANIZATION COMMITMENT AND PROFESSION FULFILMENT OF EMPLOYEES WORKING IN SOFTWARE COMPANIES OF BANGALORE
}

\author{
SAMSUDDIN ANSARI ${ }^{1}$ \& DR PREETI GARG ${ }^{2}$
}

${ }^{1}$ Research Scholar, Shobhit Institute of Engineering \& Technology, Deemed to-be University, Meerut, Uttar Pradesh, India

${ }^{2}$ Assistant Professor, Shobhit Institute of Engineering \& Technology, Deemed to-be University, Meerut, Uttar Pradesh, India

\section{ABSTRACT}

The purpose related to this paper is to identify issues affecting employee motivation and to assess their effect to profession fulfilment and organizational commitment. Research used a descriptive research approach to gather facts from workforce at various levels of IT companies in Bangalore where a hundred representatives were chosen depend on the investigator facts collected with the help of the survey. The findings of Research revealed that there is a direct and important effect on work force' motivation for their accomplishment, contentment and dedication to planning.

KEYWORDS: Profession fulfilment, IT sector, Organization Performance, Organization Commitment

Received: Aug 08, 2020; Accepted: Aug 28, 2020; Published: Nov 04, 2020; Paper Id.: IJHRMRAUG202011

\section{INTRODUCTION}

Satisfactionintheworkplaceisperhapsthemostimportantfactorthatallbusinesses need to understand about growth and development. A business that does not include profession fulfilment in the workplace often sees failure. Associations want to be gainful and prosperous, in modern era there is cut throat competition and business apart from scale, techniques and trade focus face the challenges of retaining staff. To overcome these barriers, we must create and maintain a strong, positive relationship and strengthening employees and their associations. Work force of any organization is a very important asset and therefore need to be influenced and commended for fulfilling their responsibilities. To achieve prosperity, organizations develop different competitive strategies with our competitors and increase organizational performance. Not many organizations are of the opinion that the work force and work force of any associations are its strength that can cause prosperity and success. Without satisfaction of work force no organization can improve or achieve success.

Problem Statement: The first and most important part of an organization is its work force. They areconsideredthebackboneofanycompany.Thisstudymainlyconsistsofprofessionfulfilment. Profession fulfilment is directly linked to the work force of any organization. Profession fulfilment is associated with productivity and organizational success. Companies that focus on providing satisfaction to their workforce are more likely to achieve the goals and a higher standard of organization. The great concentration of study by staff every day. The role of motivation, the role played and the compensation issues in establishing a commitment to work. Reasons for employed is satisfaction

Significance of Research: The focus of this research is on selected IT companies in Bangalore, India. The main purpose is to study the variables that affect profession fulfilment for work force. This research is important as it will highlight the motivations that work force sees as improving profession fulfilment and commitment. Managers of 
information technology companies willfind that research helps to improve work force' morale and bring profession fulfilment to their work force. An employee who is successful in his or her success, safety in the workplace, workplace, organizational resources are important to make work force happy and satisfied in the work they can strive to maintain. In addition, Research will recommend adoption policies and strategies that have reduced organizational mergers of job dissatisfaction.

\section{Job Satisfaction}

Job'ssatisfactionasamanisreflectedinhisworkandthedifferentaspectsofhisworkprofession fulfilment as a state of satisfaction satisfying or emotional well-being resulting from good judgement or knowledge of ajob.

As already stated, work contentment can be defined as attachment to profession. Megginson, Mosley, and Pietri (1982) state that persons find contentment in work when they feel enthusiastic about work, contentment from success and received acknowledgement after a good job. Since work satisfaction is influenced by the feelings of the work force, it has a profound effect on the human life.

\section{Organizational Commitment}

Organizational commitment is stated as an active response or learned pre disposition arisingfrom an assessment of job environment that connects that person to the association. There is a general consensus in literary texts that organizational commitment depends on feeling. There are 3 elements; positiveness in the aims and principles of the organization, the willingness to make effort from side of institutions, and wish to associated within stitutions.

Researchersexplainorganizationalcommitmentasframeofmindconsistingof3elementsknown as three-structural model. The three-structural model binds together the three mental regions that define the employment relationship with the management, and are the ultimate outcome once a worker decides to continue or exit the company. All parts differ in power from schedule, turns on the nature of the job.

\section{REVIEW OF LITERATURE}

Agbozoetal.,(2017).Ifworkforcedoesnothaveafriendlyworkingenvironment,floorallocation, cooperation and appreciation, as a result employee will not feel connected to the organization. It hasbeenanimportanttaskforemployerstoprovideacompleteenvironmentofassistancetotheir work force to save them from dissatisfaction. It is also clearly stated that laid off and dissatisfied workers are a danger to firms in the future. Unsatisfied employee will not work according to the needs of the manager or they will leave the factory. Eventually resulting in additional costs to maintain the current status of the firm plus the company will result in additional costs for the hiring of more work force. The company should be aware of strategies to encourage work force to continue to focus on work. In addition, enhancing the morale of work force will keep them on track and they will make better efforts for the welfare of the company.

Saba Salem et al., (2013) identified factors of Profession fulfilment among Banking Industry work force in Bahawalpur examined the effect of profession fulfilment determination on the banking industry and found that inconstant like structural guidelines policy and strategies, typeof job, correspondence, work pressure, procurement and selection processes rather than greater employee engagement and employee satisfaction.

Singh and Sundaray (2012) stated employee's relationships were essential to profession fulfilment that remained highest 
rank, as managers working in companies establish to be extremely satisfied with their relationships.

Malik et al (2011) conducted a study of organizational success: Pakistan's Telecommunications and Banking Study by selection of 103 Telecommunication organizations and various Pakistani banks discussing staff motivation, staff performance and organizational performance. Motivational workers are valuable then to poorly energetic workers.

\section{METHODOLOGY ADOPTED}

Facts have been collected from work force employed at various levels and ranking in Information Technology Companies. The number of respondents for this research is hundred. Study was conducted to identify the motivational factors. Particular work force was chosen on the basis of convenience sampling used by the investigator. The original facts were gathered through survey form. The survey form is designed in two parts. Section A includes of personal insights about respondentsandSectionBconsistsofinsightsaboutthemotivationalfactorsandpracticeusedby the administration in IT industry and also evaluates the executive fulfilment and organizational commitment.

\begin{tabular}{|l|c|}
\hline \multicolumn{1}{|c|}{ Name of Companies } & Number of Respondents \\
\hline TCS & 25 \\
\hline Oracle & 25 \\
\hline Sapient & 25 \\
\hline Wipro & 25 \\
\hline
\end{tabular}

\section{OBJECTIVES OF RESEARCH}

To identify the variables which inspire the work force of working in IT sector.

\section{Components Determining Profession Fulfilment}

The main components that determine profession fulfilment have been asserted which are as follows:

Occupation Safety: It is necessary for a person to consider himself un assailable in the workplace. Factors like fragility, inclination and inefficiency don't promote profession fulfilment. Occupational safety is influenced by variables like, exchanging views, proper work environment, good superior-subordinate relationship, proper tools and equipment's that people use for production and production, access to benefits and benefits and good pay in terms of performance. General profession fulfilment has little to do with job security.

Opportunities to Use Skills: During employment, people delighted, when they allowed to utilize their skills and knowledge. People should receive coaching and instructions time to time in their profession, which is why a person feels satisfied, given the opportunities to make the most of their education and training. When people unable to use their talent, education and knowledge in the workplace, they feel dissatisfied.

Human Resource Management: It is an integral part of every organization. It is based on the acceptance that man power of the organization as well as organization together are the same. Sound commerce often sees middle-class work force as the main source of product profits. These organizations view work force instead of money as the basic foundations of trade and commerce ingrowthoforganizations.Toachievetargets,anorganizationdevelopsanambienceofconfidence as well aiding and encouragement from its people through plans, strategies that give employees contentment. Workforce is motivated and develops a loyalty or commitment to the company that leads to greater performance and lower price levels.

Payments: Indemnification is stated as a financial reward provided to work force by a company for rendering their duties. 
Payments are important component for which work force work, where they believe are adequate to earn a livelihood, where they feel contentment about their service.

Peoplereceivepromotionsandincreasespaymentgivesgreaterjoyandcontentmentintheirwork. Payments and rewards takes precedence in determining profession fulfilment compared to other major decisions.

Managerial Support: In an organization, employees need direction, guidance from peers and supervisors. Administrator direction is vital factor in retaining work force and performing responsibilities. Managerial guidance is stated as the level at

which leaders and managers per form forthewelfareofpeopleandappreciatetheirendowments.Employeesbelievethattheyaregetting encouragement, relief, help and comfort from manager, they feel valued, listened to and cared for, which is why, as a result, they feel delighted with job.

Table 1: Demographic Profile of Respondents

\begin{tabular}{|c|c|c|}
\hline Age of Work force in (Percentage) & Age & $\begin{array}{l}\text { Number of } \\
\text { Respondents }\end{array}$ \\
\hline & 20 years \& below & 10 \\
\hline & 21 years to 29 years & 27 \\
\hline & 29 years to 39 years & 26 \\
\hline & 39 years to 49 years & 20 \\
\hline & 49 years \& above & 17 \\
\hline Total & & 100 \\
\hline \multirow[t]{3}{*}{ Marital Status } & Married & 52 \\
\hline & Unmarried & 34 \\
\hline & Divorced & 14 \\
\hline Total & & 100 \\
\hline \multicolumn{3}{|l|}{ Family Type } \\
\hline & Nuclear & 46 \\
\hline & Joint Family & 54 \\
\hline Total & & 100 \\
\hline \multicolumn{3}{|l|}{ Number of Children's } \\
\hline & Yes & 64 \\
\hline & No & 36 \\
\hline Total & & 100 \\
\hline \multirow[t]{5}{*}{ Education Status of Respondents } & Qualification & \\
\hline & Doctorate Degree's & 18 \\
\hline & Post Graduate & 31 \\
\hline & Graduate & 38 \\
\hline & Diploma & 13 \\
\hline Total & & 100 \\
\hline
\end{tabular}

Table 2: Motivational factors affecting work force working in IT sector

\begin{tabular}{|l|c|c|c|c|}
\hline \multicolumn{1}{|c|}{ Motivational Factors } & T & df & Sig(2 tailed) & Mean diff. \\
\hline Compensation & 4.348 & 50 & 0.000 & 0.660 \\
\hline Superior/subordinate relationship & 0.653 & 62 & 0.214 & 0.214 \\
\hline Working environment & -1.728 & 45 & 0.000 & 0.745 \\
\hline
\end{tabular}




\begin{tabular}{|l|c|c|c|c|}
\hline Participate in decision making & 3.733 & 51 & 0.000 & 0.589 \\
\hline Job Security & 9.150 & 53 & 0.000 & 0.128 \\
\hline Recognition Programs & 3.682 & 58 & 0.024 & 0.438 \\
\hline Career Development & 0.851 & 58 & 0.245 & 0.774 \\
\hline Training & 3.503 & 34 & 0.256 & 0.476 \\
\hline Flexible Work Arrangements & 4.761 & 34 & 0.022 & 0.327 \\
\hline
\end{tabular}

Above mentioned table exhibit variables which are important for motivating work force working in IT sector. Observation used to determine the important variable is $t$ value $>0$ and sigma $<.05$. accordingly, 9 variables i.e. monetary compensation, superior-subordinate relationship, working environment, people management, job security, recognition programs, career development, non- monetary benefits, flexible work arrangements, these factors proved to be significant.

\section{CONCLUSIONS}

Motivation plays a key role in employee performance leading to increased profession accomplishment and alike commitment to planning. Study evaluated the size or diversity of the promotions mentioned contributes to the administrative allegiance of work force of TechnologycompaniesinBangalore.Otherinnovationsemergedthatareconsideredtobethemost powerful motivational factors and are able to create variations by approximately $64 \%$ at the level of employee motivation. By providing flexible work arrangements, a healthy work environment, informingworkforceofcompletionoftaskandinvolvingtheminregulating, intrinsic satisfaction of work, and working conditions. As a result, zeal for the job increases, leading to improved concert. Highly motivated work force is an essential strength for organization. These work force improve productivity and faithful to institutions. It is proposed that managers should offer training to work force at every level, provide services, rewards for good results besides to motivate them but also to build a desire to compete and achieve high.

\section{REFERENCES}

1. Harder, M. (2008). How Do Rewards and Management Styles Influence the Motivation to Share Knowledge? Centre for Strategic Management and globalization 3(5).

2. Herzberg, F. (1966), Work and Nature of Man, Cleveland: World.

3. MATHAPATI, CM. "STRESS AND VOLUNTARY TURNOVER: AN EMPIRICAL ANALYSIS WITH SPECIAL REFERENCE TO SOFTWARE EMPLOYEES IN BANGALORE, INDIA." International Journal of Human Resource Management and Research (IJHRMR) 9.1, Apr 2019, 1-10

4. Jaafar, M., Ramayah, T. and Zainal, Z. (2006). Work Satisfaction and Work Performance: How Project Managers in Malaysia Perceive It? Academy of World Business, Marketing and Management Development Conference Proceedings, 2(113), 13051313.

5. Kinicki, A., \& Kreitner, R., (2003). Organizational behavior: Key concepts, skills and best practices. New York: McGraw-Hill.

6. ANUPAMA, G., and VVS KESAVA RAO. "PERFORMANCE EVALUATION OF SOFTWARE COMPANIES USING DEA METHODS IN FUZZY ENVIRONMENT." International Journal of Mechanical and Production Engineering Research and Development (IJMPERD) 9.6, Dec 2019, 279-292

7. Locke, E.A. (1976). The Nature and causes of profession fulfillment. In M.D. Dunnette (Ed.),

8. Handbook of industrial and organizational psychology, 1297-1343. 
9. Locke, E.A. and Letham, G.P. (2004). What Should We Do About Motivation Theory? Six Recommendations for the TwentyFirst Century, Academy of Management Review, 29(3), 388- 403.

10. MATHAPATI, CM. "STRESS AND VOLUNTARY TURNOVER: AN EMPIRICAL ANALYSIS WITH SPECIAL REFERENCE TO SOFTWARE EMPLOYEES IN BANGALORE, INDIA." International Journal of Human Resource Management and Research (IJHRMR) 9.1, Apr 2019, 1-10

11. Malik, M.E., Ghafoor, M.M. and Naseer, S. (2011). Organizational Effectiveness: A Case Study ofTelecommunicationandBankingSectorofPakistan.EastJournalofPsychologyandBusiness, 2, 37-49.

12. Megginson, L.C., Mosley, D.C., \& Pietri, P.H. (1982). Management concepts and applications

13. (4th ed.). New York: Harper Collins.

14. Preeti Garg \& Neha Yajurvedi (2016). Impact of Work-Life Balance Practices on Work force Retention and Organizational Performance - A Study on IT Industry.IJAR. 6(8),105-108

15. TRIVEDI, PRACHI, and MEGHNA SHARMA. "Impact Of Green Production And Green Technology On Sustainability: Cases On Companies In India." International Journal of Mechanical and Production Engineering Research and Development (IJMPERD) (2017).

16. Preeti Garg \& Ayushi Parmar (2019). Impact of Training and Development on Profession fulfillment of Bank Work force: A Study in Ghaziabad City. Journal of Emerging Technologies and Innovative Research. 6(5), 203-208 